\title{
RESEARCH
}

Open Access

\section{Validity of fibromyalgia survey questionnaire (2016) assessed by telephone interview and cross-cultural adaptation to Brazilian Portuguese language}

\author{
Jordana Bernardi Daltrozo', Juliane Aline Paupitz ${ }^{2}$ and Fabricio Souza Neves ${ }^{1,2^{*}}$ (D)
}

\begin{abstract}
Background: To verify the validity of the 2016-revised Fibromyalgia Survey Questionnaire (FSQ) by telephone interview compared to self-administration and to produce a valid version of FSQ in Brazilian Portuguese language.

Methods: The Brazilian version of FSQ was produced following the recommendations for cross-cultural adaptation. Validity of Brazilian FSQ self-administration was assessed by checking agreement of its results with fibromyalgia diagnosis according the 1990 American College of Rheumatology (ACR) criteria. Reproducibility and validity of FSQ by telephone were assessed by comparing its results with the previous FSQ self-administration.

Results: A Brazilian Portuguese version (FSQ-Brazil) was produced. FSQ-Brazil had good internal consistency (Cronbach's alpha between 0.73 and 0.94). Agreement between the results obtained by self-administration of FSQBrazil and by telephone interview was substantial or almost perfect for almost all questions about pain sites and all questions about other somatic symptoms (Cohen's kappa higher than 0.6). There were small but significant bias toward higher scores of widespread pain index and fibromyalgia severity scale in the telephone interview compared to self-administration. Fibromyalgia definition by self-administration and telephone interview with FSQBrazil both revealed substantial agreement with the diagnosis based on ACR 1990 criteria (Cohen's kappa 0.62 and 0.65 ; respectively).

Conclusions: FSQ-Brazil demonstrated good internal consistency, reproducibility and validity both by selfadministration and by telephone interview. However, caution must be taken with the interpretation of quantitative scores of widespread pain index and symptoms severity scale, which slightly differed according the method (selfadministration or interview) in our study.
\end{abstract}

Keywords: Fibromyalgia, Cross-cultural comparison, Validation studies, Telephone

\footnotetext{
* Correspondence: fabricio.souza.neves@ufsc.br

'Graduate Program in Medical Sciences, Health Sciences Center, Federal

University of Santa Catarina (UFSC), Florianópolis, Brazil

${ }^{2}$ Internal Medicine Department- University Hospital, 3rd floor, Health Sciences

Center, Federal University of Santa Catarina (UFSC), Rua Profa. Maria Flora

Pausewang, s/n. CEP 88036-800, Trindade, Florianópolis, SC, Brazil
}

(c) The Author(s). 2020 Open Access This article is licensed under a Creative Commons Attribution 4.0 International License, which permits use, sharing, adaptation, distribution and reproduction in any medium or format, as long as you give

appropriate credit to the original author(s) and the source, provide a link to the Creative Commons licence, and indicate if changes were made. The images or other third party material in this article are included in the article's Creative Commons licence, unless indicated otherwise in a credit line to the material. If material is not included in the article's Creative Commons licence and your intended use is not permitted by statutory regulation or exceeds the permitted use, you will need to obtain permission directly from the copyright holder. To view a copy of this licence, visit http://creativecommons.org/licenses/by/4.0/ 


\section{Background}

The 2010 American College of Rheumatology (ACR) fibromyalgia criteria allows its diagnosis without the requirement for tender point ascertainment, which was the basis of 1990 ACR criteria, but was still based on physician assessment [1]. Their modification performed in 2011 allows the evaluation to be entirely accomplished by self-report. Thus it stablished an instrument suitable to assess fibromyalgia for surveys, eliminating the need for an examiner. It was called Fibromyalgia Survey Questionnaire (FSQ) [2] and its latest revision was performed in 2016 [3].

FSQ is composed of two scales: widespread pain index (WPI, 0-19 points), based on the self-report of painful body sites; and the symptom severity scale (SSS, 0-12 points), based on the self-report of intensity of somatic symptoms. The fibromyalgia severity scale (FSS) can be calculated by the sum of WPI and FSS (0-33 points). Pain sites were grouped into five regions, and diagnosis of fibromyalgia can be done if: 1) there is pain in at least four of the five regions; 2) symptoms are present for at least 3 months; 3) WPI is greater than or equal to seven and the SSS is greater than or equal to five or WPI is four to six and the SSS is greater than or equal to nine [3].

Since FSQ is a self-administration instrument, and the diagnosis of fibromyalgia can be made independently of the concomitance of other diagnoses, FSQ is potentially useful also for telemedicine purposes, if it may be reliably performed by a telephone interview. As far as we know, there are no studies evaluating the psychometric properties of FSQ by telephone. Considering that FSQ is based on questions directed to the tested subjects, proper cross-cultural adaptation is needed before being used in any population. Therefore, the aims of this study were to produce the Brazilian Portuguese language version of FSQ and assess its reliability and validity by selfadministration and by telephone interview.

\section{Methods}

We included all patients attending a tertiary outpatient rheumatology public service and a private internal medicine practice who agreed to be submitted to the study procedures, between September, 2018, and April, 2019, regardless of its diagnosis. Of note, none of these services was a referral for fibromyalgia patients. Minimum sample size was estimated as 60 subjects (10 subjects for each item of the questionnaire). Sample size was also estimated at 73 participants, in order to identify the proportion of individuals with fibromyalgia, considering the expected prevalence of fibromyalgia in an outpatient service as $5 \%$, with a margin of error of $5 \%$ and $\alpha 0.05$. The study was approved by National Committee for Research Ethics. All patients signed written informed consent. Inclusion criteria was age between 18 and 65 years old, including these values. Exclusion criteria were inability to read the instrument for self-application due to illiteracy or visual impairment.

For the process of cross-cultural adaptation, the "Guidelines of Institute for Work and Health" [4] were applied after authorization of the main author of the original FSQ. Initially the FSQ in English language was translated to Brazilian Portuguese by two independent bilingual Brazilian translators: a physician (T1) and a non-medical translator, without knowledge on the subject (T2). They summarized both translations producing a single consensual version called T12. From T12, two different back-translations to English were produced by two independent English native non-medical translators (BT1 and BT2). A panel composed by the researchers and all translators, with the support of Portuguese and English teachers, evaluated all reported data, solved the discrepancies and created the pre-final version of the questionnaire.

In the pre-final version, after each topic of the instrument, it was included a Likert scale in order to the patients score each item: "I did not understand anything; I understood a little; I understood part of this item; I understood almost everything; I completely understood this item". At the pre-test phase, the instrument was submitted to a sample of subjects by self-administration, under observation of the investigator. The subjects were asked to express any doubt on reading each item. Items that obtained $80 \%$ or more of responses "I completely understood this item" were considered to have cultural equivalence to the original instrument. Items with lower understanding rates or with relevant doubts expressed by the subjects were discussed again by the panel of investigators and translators, adapted and tested again until reached satisfactory response rates. The final version of the instrument was called "FSQ-Brazil" (Fig. 1).

Test phase consisted in three procedures. In the first step, all subjects were submitted to the selfadministration of FSQ-Brazil. Additionally, data about demographic and clinical characteristics of the subjects were also obtained. In the second step, subjects were conducted to the rheumatologist (FSN) office, in the same day of the first step, to be submitted to clinical interview and physical examination with tender points assessment, for fibromyalgia evaluation according ACR 1990 [5]. The rheumatologist was not aware about the results of FSQ-Brazil. In the third step, patients were called by telephone 24 to $48 \mathrm{~h}$ later by another investigator (JBD, who was also not aware about the results of the preceding evaluations), in order to be submitted to a remote spoken interview with the administration of FSQ-Brazil.

Internal consistency of FSQ-Brazil was assessed by Cronbach's alpha statistic between WPI, SSS and FSS 
Questionário de Pesquisa em Fibromialgia

(Fibromyalgia Survey Questionnaire)

FSQ-Brazil

Pergunta 1: (índice de Dor Generalizada-WPI)
Por favor, indique se você teve DOR OU DESCON
Faça um X se você teve dor ou desconforto.
Região 1
( ) Lado esquerdo da mandíbula (queixo)
( ) Ombro esquerdo
( ) Braço esquerdo
(entre o ombro e cotovelo esquerdo)
() Antebraço esquerdo
(entre o cotovelo e a mão esquerda)
Região 3
( ) Quadril esquerdo
() Coxa esquerda
() Parte inferior da perna esquerda
(entre o joelho e o pé esquerdo)

Perguntas 2-5: (Escala de Gravidade dos Sintomas-SSS)

Pergunta 2:

Nos últimos 7 DIAS, você sentiu FADIGA OU CANSAÇO? (circule uma das letras, de acordo com a intensidade que você sentiu) A - Não senti

B - Sintoma leve ou suave, senti de vez em quando

C - Sintoma médio, senti frequentemente

D - Sintoma forte, senti continuamente, atrapalhando a rotina

Pergunta 3:

Nos últimos 7 DIAS, você teve um SONO NÃO REPARADOR, ACORDOU CANSADO, como se não tivesse dormido o suficiente?

(circule uma das letras, de acordo com a intensidade que você sentiu)

A- Não senti

B- Sintoma leve ou suave, senti de vez em quando

C- Sintoma médio, senti frequentemente

D- Sintoma forte, senti continuamente, atrapalhando a rotina

Pergunta 4:

Nos últimos 7 DIAS, você sentiu DIFICULDADE DE RACIOcínIO OU DE MEMÓRIA? (circule uma das letras, de acordo com a intensidade que você sentiu)

A - Não senti

B - Sintoma leve ou suave, senti de vez em quando

C - Sintoma médio, senti frequentemente

D - Sintoma forte, senti continuamente, atrapalhando a rotina

Pergunta 5:

Durante os últimos 6 MESES, você sentiu:

$\begin{array}{lll}\text { Dor de cabeça } & \operatorname{Sim}(\text { ) } & \text { Não ( ) } \\ \text { Dor ou cólicas em abdome inferior (abaixo do umbigo) } & \operatorname{Sim}() & \text { Não ( ) }\end{array}$

Depressão / tristeza $\quad \operatorname{Sim}() \quad$ Não $($ )

Pergunta 6:

Considerando todas as perguntas deste questionário, em geral, os sintomas que você sentiu estiveram frequentemente Considerando todas as perguntas dest
presentes por pelo menos 3 MESES?

$\begin{array}{ll}\text { Região } 2 & \text { Região } 5 \\ \begin{array}{l}\text { ( ) Lado direito da mandíbula (queixo) } \\ \text { ( ) Ombro direito }\end{array} & \text { ( ) Pescoço } \\ \text { ( ) Braço direito } & \text { () Parte superior das costas } \\ \text { (entre o ombro e cotovelo direito) } & \text { () Parte inferior das costas } \\ \begin{array}{l}\text { () Antebraço direito } \\ \text { (entre o cotovelo e a mão direita) }\end{array} & \text { () Peito (tórax) } \\ \text { Região } 4 & \\ \text { ( ) Quadril direito } & \text { () Nenhuma dor em qualquer } \\ \text { () Coxa direita } & \text { dessas áreas }\end{array}$

Coxa direita

Parte inferior da perna direita

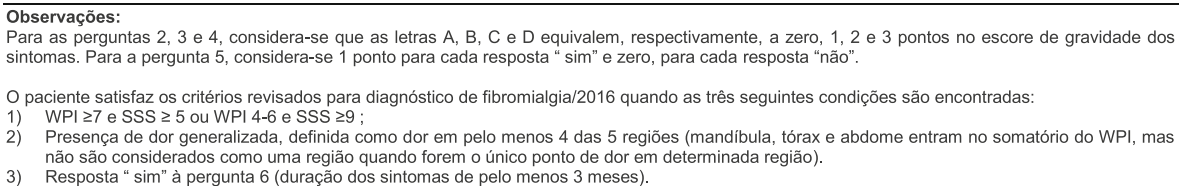

Fig. 1 Fibromyalgia Survey Questionnaire

domains of the instrument. Reproducibility of FSQBrazil by telephone interview was assessed by agreement between its results with FSQ self-administration, according to Cohen's kappa statistics. The possibility of bias between telephone and self-administration FSQ was assessed by Wilcoxon test. $P$-values less than 0.001 were considered statistically significant $(0.05$ adjusted by Bonferroni's correction for 34 multiple comparisons).

Construct validity of FSQ-Brazil was assessed by checking their results with the fibromyalgia diagnosis according the 1990 American College of Rheumatology (ACR) criteria. Agreement between the diagnoses were assessed by
Cohen's Kappa statistics. Furthermore, correlations of WPI and FSS obtained by FSQ-Brazil with tender points counts by the rheumatologist were assessed by the Spearman's test. Also, sensitivity and specificity of FSQ-Brazil were calculated considering the rheumatologist diagnosis according to ACR 1990 criteria as the gold standard. All statistical analysis was performed with GNU PSPP 1.2.0๑, Free Software Foundation.

\section{Results}

In the pre-test step, the pre-final version was applied to 50 subjects, mean age $45 \pm 12$ years old, 46 (90.2\%) 
female. As for educational level, 52.0\% had undergraduate level, 38.0\% had high school level and 10.0\% had elementary and middle school level. All items of the instrument achieved more than $80 \%$ of "complete understanding" responses. The instrument FSQ-Brazil is showed in Fig. 1.

In the self-administration of FSQ-Brazil (first step), 116 subjects were initially enrolled, but one patient needed to be excluded from the study because of illiteracy and 15 were excluded because would not be available for the telephone interview. A sample of 100 subjects was then included, with mean age $44 \pm 13$ years old, 90 (90.0\%) female. As for educational level, 60.0\% had undergraduate level, $31.0 \%$ had high school level and $9.0 \%$ had elementary and middle school level. Regarding painful chronic diseases, $13(13.0 \%)$ of patients had the previous diagnosis of fibromyalgia, 9 (9.0\%) had systemic lupus erythematosus, 7 (7.0\%) had rheumatoid arthritis, 7 (7.0\%) had systemic vasculitis, 3 (3.0\%) had systemic sclerosis, 2 (2.0\%) had Sjögren syndrome and 2 (2.0\%) had generalized osteoarthritis. From this sample, 87 subjects were submitted to examination of tender points (second step) and all 100 answered the telephone interview (third step). In the self-administration of FSQ only three missing items (without answer) were observed. All of them were the WPI question and, in all cases, patients wrote a note meaning "I have no pain", thus we interpreted these cases as WPI equals "zero". Median time between self-administration of FSQ-Brazil and telephone interview was $24 \mathrm{~h}$. By the selfadministration of FSQ-Brazil 27/100 subjects (27.0\%) satisfied the 2016 diagnostic criteria of fibromyalgia; according the rheumatologist assessment, 27/87 subjects (31.0\%) were diagnosed as having fibromyalgia by the 1990 ACR criteria; and by the telephone interview with FSQ-Brazil 33/100 subjects (33.0\%) satisfied the 2016 diagnostic criteria of fibromyalgia. The internal consistency between the domains of FSQ-Brazil was substantial, Cronbach's alpha between 0.73 and 0.94, with similar performance in self-administration and telephone interview (Table 1).

Agreement between the results obtained by telephone interview and self-administration of FSQ-Brazil was

Table 1 Internal consistency of Fibromyalgia Survey Questionnaire (Brazil): telephone interview and selfadministration

\begin{tabular}{lll}
\hline & $\begin{array}{l}\text { FSQ-Brazil (telephone) } \\
\text { Cronbach's a }\end{array}$ & $\begin{array}{l}\text { FSQ-Brazil (self-administration) } \\
\text { Cronbach's a }\end{array}$ \\
\hline WPI and SSS & 0.73 & 0.74 \\
WPI and FSS & 0.94 & 0.94 \\
SSS and FSS & 0.75 & 0.76
\end{tabular}

FSQ Fibromyalgia Survey Questionnaire, WPI widespread pain index, SSS symptom severity scale, FSS fibromyalgia severity scale
Table 2 Reproducibility of Fibromyalgia Survey Questionnaire (Brazil) by telephone interview

\begin{tabular}{|c|c|c|c|c|}
\hline & \multirow[t]{2}{*}{ Reproducibility } & \multicolumn{3}{|l|}{ Bias } \\
\hline & & Phone & Self & $p$ \\
\hline$\overline{W P I}$ & $0.91 \pm 0.02$ & $5[8]$ & $4[8]$ & $<0.001^{*}$ \\
\hline Region 1 (left upper) & $0.74 \pm 0.07$ & $52 \%$ & $41 \%$ & 0.002 \\
\hline Left jaw & $0.70 \pm 0.09$ & $25 \%$ & $17 \%$ & 0.011 \\
\hline Left shoulder & $0.59 \pm 0.08$ & $47 \%$ & $34 \%$ & 0.003 \\
\hline Left upper arm & $0.73 \pm 0.08$ & $30 \%$ & $25 \%$ & 0.132 \\
\hline Left lower arm & $0.83 \pm 0.07$ & $25 \%$ & $21 \%$ & 0.102 \\
\hline Region 2 (right upper) & $0.68 \pm 0.07$ & $56 \%$ & $44 \%$ & 0.003 \\
\hline Right jaw & $0.64 \pm 0.09$ & $26 \%$ & $16 \%$ & 0.004 \\
\hline Right shoulder & $0.59 \pm 0.08$ & $46 \%$ & $34 \%$ & 0.007 \\
\hline Right upper arm & $0.64 \pm 0.08$ & $36 \%$ & $28 \%$ & 0,046 \\
\hline Right lower arm & $0.70 \pm 0.08$ & $29 \%$ & $25 \%$ & 0.248 \\
\hline Region 3 (left lower) & $0.82 \pm 0.06$ & $51 \%$ & $48 \%$ & 0.317 \\
\hline Left hip & $0.89 \pm 0.05$ & $40 \%$ & $37 \%$ & 0.180 \\
\hline Left upper leg & $0.72 \pm 0.09$ & $22 \%$ & $19 \%$ & 0.317 \\
\hline Left lower leg & $0.62 \pm 0.08$ & $35 \%$ & $32 \%$ & 0.467 \\
\hline Region 4 (right lower) & $0.84 \pm 0.05$ & $45 \%$ & $45 \%$ & 1.000 \\
\hline Right hip & $0.75 \pm 0.07$ & $34 \%$ & $33 \%$ & 0.763 \\
\hline Right upper leg & $0.71 \pm 0.09$ & $22 \%$ & $22 \%$ & 1.000 \\
\hline Right lower leg & $0.77 \pm 0.07$ & $31 \%$ & $31 \%$ & 1.000 \\
\hline Region 5 (axial) & $0.66 \pm 0.08$ & $71 \%$ & $71 \%$ & 1.000 \\
\hline Neck & $0.54 \pm 0.08$ & $57 \%$ & $50 \%$ & 0.144 \\
\hline Upper back & $0.70 \pm 0.07$ & $48 \%$ & $43 \%$ & 0.197 \\
\hline Lower back & $0.63 \pm 0.08$ & $45 \%$ & $39 \%$ & 0.157 \\
\hline Chest & $0.78 \pm 0.08$ & $23 \%$ & $16 \%$ & 0.008 \\
\hline Abdomen & $0.69 \pm 0.09$ & $22 \%$ & $18 \%$ & 0.206 \\
\hline SSS & $0.89 \pm 0.03$ & $6[6]$ & $6[5]$ & 0.614 \\
\hline Fatigue & $0.64 \pm 0.06$ & $1[2]$ & $1[1]$ & 0.403 \\
\hline Waking unrefreshed & $0.60 \pm 0.06$ & $2[3]$ & $1.5[1]$ & 0.120 \\
\hline Cognitive symptoms & $0.69 \pm 0.06$ & 1 [2] & $1[2]$ & 0.827 \\
\hline Headaches & $0.83 \pm 0.07$ & $77 \%$ & $79 \%$ & 0.414 \\
\hline Abdominal pain & $0.62 \pm 0.08$ & $49 \%$ & $48 \%$ & 0.819 \\
\hline Depression & $0.89 \pm 0.05$ & $63 \%$ & $64 \%$ & 0.655 \\
\hline 3 months & $0.47 \pm 0.10$ & $83 \%$ & $69 \%$ & 0.002 \\
\hline FSS & $0.94 \pm 0.01$ & $11[13]$ & $9[11]$ & $<0.001^{*}$ \\
\hline
\end{tabular}

WPI widespread pain index, SSS symptom severity scale, FSS fibromyalgia severity scale

All reproducibility results are Cohen's kappa values, except for WPI, SSS and FSS (Spearman's R) \pm standard errors. All bias results are $p$ values of Wilcoxon tests. Results of WPI, SSS, FSS, "fatigue", "waking unrefreshed" and "cognitive symptoms" are shown as median [interquartile range]. * indicates $p$ values that were considered statistically significant $(<0.001$, according Bonferroni correction for multiple comparisons)

substantial or almost perfect (Cohen's kappa higher than 0.6 ) for almost all pain sites (WPI items), except for left shoulder (kappa 0.59) and neck (kappa 0.54). Substantial 
or almost perfect agreement also occurred with all questions about symptoms severity (SSS items). The worst agreement occurred with the question "Symptoms have been generally present for at least 3 months?" (kappa 0.47). Correlations between telephone and selfadministered WPI, SSS and FSS were strong (Table 2). It is worth highlighting that there were small but statistically significant bias toward higher scores in telephone interview than in self-administration of WPI (5 [8] vs 4 [8], $p<0.001)$ and FSS (11[13] vs 9 [11], p $<0.001)$. Major deviations occurred in the upper left region (region 1) and upper right region (region 2) of pain sites. SSS results were quite similar between telephone interview and self-administration of FSQ (Table 2).

The diagnosis of fibromyalgia by self-administration and telephone interview with FSQ-Brazil both revealed substantial agreement with the diagnosis based on ACR 1990 criteria (Cohen's kappa 0.62 and 0.65, respectively). Sensitivity of FSQ-Brazil was $66.7 \%$ (self-administration) and $77.8 \%$ (telephone), but the difference was not statistically significant. Specificity was $88.3 \%$ in both (self-administration and telephone). Correlations between WPI, SSS and FSS with tender points counts by rheumatologist examination were all strong (Spearman's $\mathrm{R}$ higher than 0.6) (Table 3).

\section{Discussion}

In our study, we produced a culturally equivalent version of FSQ in Brazilian Portuguese language, based on the 2016 revision of fibromyalgia diagnostic criteria [3], and tested its psychometric properties. FSQ-Brazil, as a self-administration instrument, has good internal consistency, as well as other versions already translated from FSQ [6-8].

There are some studies about reproducibility of results between telephone interview and selfadministration of diagnostic instruments. This evaluation is necessary before using any instrument in a telephone survey or for telemedicine purposes. For example, the modified Rankin Scale (mRS), a functional assessment instrument for stroke patients, was validated for telephone interview in 2012 [9]. Also, a version of the International Consultation on Incontinence Questionnaire (ICIQ) was recently developed for use in electronic mobile devices [10].

As far as we know, our study is the first to demonstrate the reproducibility of the FSQ instrument when applied by a telephone interview. A study with German pediatric chronic pain patients found that reproducibility of pain measurement scales was substantial or excellent for telephone interview comparing to self-administration of questionnaires. In this study, information on some pain locations (extremities and back) had small but significant differences in the two methods [11]. Our results also indicate that significantly higher scores of WPI and FSS were obtained in telephone administration of FSQ, but the differences were small and did not compromise the overall reproducibility of FSQ. To explain these differences, we may suggest that for Brazilian adult patients (our study population, noteworthy that $90 \%$ of our study population were female), spoken language is an easier way to express their painful symptoms than a written questionnaire. It is worth mentioning that there was a trend to higher sensitivity of FSQ-Brazil by telephone interview than self-administration, which could be compatible with this hypothesis, but statistical significance was not observed. In addition, several forms of biases may alternatively explain this finding. Memory bias is the most important because telephone interview was always performed after FSQ self-administration in our study, in most of cases $24 \mathrm{~h}$ later. Also, we need to consider that tender points examination was performed before telephone interview, which may influence pain description by the patient. Of note, in our population FSQ-Brazil was less sensitive than specific for fibromyalgia diagnosis according ACR 1990 criteria based on tender points physical assessment. We can suppose that a written self-administration of FSQ-Brasil may leave unnoticed some fibromyalgia cases that could be diagnosed by closer approaches as a spoken interview and a physical palpation. In addition, it is necessary to note that patients with chronic disease, some of them possible pain generators, composed our study population and this may

Table 3 Construct validity of Fibromyalgia Survey Questionnaire (Brazil): telephone interview and self-administration

\begin{tabular}{|c|c|c|c|c|c|}
\hline & \multicolumn{5}{|c|}{ ACR 1990} \\
\hline & \multicolumn{3}{|c|}{ Fibromyalgia diagnosis } & & \multirow{2}{*}{$\begin{array}{l}\text { Tender points coun } \\
\text { Spearman }\end{array}$} \\
\hline & & & Kappa & & \\
\hline \multirow[t]{2}{*}{ FSQ-BR phone } & Se & $77.8 \%[57.7-91.3]$ & $0.65 \pm 0.09$ & WPI & $0.76 \pm 0.05$ \\
\hline & Sp & $88.3 \%$ [77.4-95.1] & & FSS & $0.77 \pm 0.05$ \\
\hline \multirow[t]{2}{*}{ FSQ-BR self } & Se & $66.7 \%[46.0-83.5]$ & $0.62 \pm 0.09$ & WPI & $0.68 \pm 0.06$ \\
\hline & Sp & $88.3 \%$ [77.4-95.2] & & FSS & $0.72 \pm 0.05$ \\
\hline
\end{tabular}

FSQ Fibromyalgia Survey Questionnaire, Br Brazil, WPI widespread pain index, SSS symptom severity scal, FSS fibromyalgia severity scale, Se sensitivity, Sp Specificity

Results are shown with \pm standard errors or [95\% confidence interval] 
have influenced our results. Also, in our study $60.0 \%$ of patients had undergraduate educational level, which certainly differ of Brazilian population in other regions. Therefore, more studies are still necessary to evaluate the diagnostic properties of FSQ for individual cases in the general population.

In Brazil, symptoms compatible with fibromyalgia are among the most common complaints leading to consultation in primary care (low back pain, headache, abdominal cramps, weakness, diffuse arthralgia). However, fibromyalgia does not even appear in the list of most frequent diagnosis in the primary care of Brazilian health system [12]. This suggests that fibromyalgia may be underdiagnosed in our country, which could lead to suboptimal treatment for these patients with chronic pain. Therefore, a reliable and easy-to-use instrument for the diagnosis of fibromyalgia would be of great value for primary care physicians. In Brazil, a program called Telessaúde (remote health care) gives support to the national public health system by remote consultation between primary care physician and specialists. In a system like this, a set of diagnostic criteria as FSQ would be helpful to improve communication between primary care physicians and rheumatologists. However, our results does not suggest that FSQ-Brazil (particularly on selfapplication method) could replace clinical assessment for individual diagnoses.

\section{Conclusions}

A version of Fibromyalgia Survey Questionnaire (FSQ) for Brazilian population was produced (FSQ-Brazil). FSQ-Brazil demonstrated good internal consistency, reproducibility and validity both by self-administration and by telephone interview, therefore it can be used in surveys by telephone. However, caution must be taken with the interpretation of quantitative scores of widespread pain index and symptoms severity scale, which slightly differed according the method (self-administration or interview) in our study.

\section{Abbreviations}

ACR : American College of Rheumatology; FSQ: Fibromyalgia Survey Questionnaire; FSQ-Brazil: Fibromyalgia Survey Questionnaire - Brazilian Portuguese version; FSS: Fibromyalgia Severity Scale; SSS: Symptom Severity Scale; WPI: Widespread Pain Index

\section{Acknowledgements}

Acknowledgements: The authors are grateful to Hospital Universitário Prof. Polydoro Ernani de São Thiago / EBSERH, for allowing the study to be carried out at his premises.

\section{Datasets}

The datasets used and/or analysed during the current study are available from the corresponding author on reasonable request.

\section{Publication}

The content of the manuscript has not been published, or submitted for publication elsewhere.

\section{Authors' contributions}

JBD and FSN collected, analyzed and interpreted the patient data. JAP analyzed the results and was a major contributor in writing the manuscript. All authors read and approved the final manuscript, and give their consent for publication.

\section{Funding}

There is no funding to be reported.

\section{Availability of data and materials}

The datasets used and/or analysed during the current study are available from the corresponding author on reasonable request.

\section{Ethics approval and consent to participate}

The study was approved by National Committee for Research Ethics. All patients signed written informed consent.

\section{Consent for publication}

All authors read and approved the final manuscript and give their consent for publication.

\section{Competing interests}

The authors declare that they have no competing interests.

Received: 11 May 2020 Accepted: 1 July 2020

Published online: 16 July 2020

\section{References}

1. Wolfe F, Clauw DJ, Fitzcharles M, Goldenberg DL, Katz RS, Mease P, et al. The american College of Rheumatology preliminary diagnostic criteria for fibromyalgia and measurement of symptom severity. Arthritis Care Res. 2010;62:610-20.

2. Wolfe F, Clauw DJ, Fitzcharles M, Goldenberg DL, Häuser W, Katz RS, et al. Fibromyalgia criteria and severity scales for clinical and epidemiological studies: a modification of the ACR preliminary diagnostic criteria for fibromyalgia. J Rheumatol. 2011;38:1113-22.

3. Wolfe F, Clauw DJ, Fitzcharles M, Goldenberg DL, Häuser W, Katz RS, et al. 2016 revisions to the 2010/2011 fibromyalgia diagnostic criteria. Semin Arthritis Rheum. 2016:46:319-29.

4. Beaton DE, Bombardier C, Guillemin F, Ferraz MB. Guidelines for the process of cross-cultural adaptation of self-report measures. Spine. 2000;25:3186-91.

5. Wolfe F, Smythe HA, Yunus MB, Bennett RM, Bombardier C, DI G, et al. The American College of Rheumatology 1990 criteria for the classification of fibromyalgia. Arthritis Rheum. 1990;33:160-72.

6. Fitzcharles M, Ste-Marie PA, Panopalis P, Ménard H, Shir Y, Wolfe F. The 2010 American college of rheumatology fibromyalgia survey diagnostic criteria and symptom severity scale is a valid and reliable tool in a French speaking fibromyalgia cohort. BMC Musculoskelet Disord. 2012:13:179.

7 Häuser W, Jung E, Erbslöh-Möller B, Gesman M, Kühn-Becker H, Petermann, et al. Validation of the Fibromyalgia Survey Questionnaire within a CrossSectional Survey. PLoS One. 2012;7:e37504.

8 Usui C, Hatta K, Aratani S, Yagishita N, Nishioka K, Kanazawa T, et al. The Japanese version of the modified ACR preliminary diagnostic criteria for fibromyalgia and the fibromyalgia symptom scale: reliability and validity. Mod Rheumatol. 2013;23:846-50.

9. Dennis M, Mead G, Doubal F, Graham C. Determining the modified Rankin score after stroke by postal and telephone questionnaires. Stroke. 2012;43: 851-3.

10 Uren AD, Cotterill N, Parke SE, Abrams P. Psychometric equivalence of electronic and telephone completion of the ICIQ modules. Neurourol Urodyn. 2017;36:1342-9.

11. Wager J, Barth F, Stahlschmidt L, Zernikow B. Testing the validity of telephone interviews to assess chronic pain in children and adolescents: a randomized cross-over trial. Eur J Pain. 2017;21:1707-16.

12. Pimentel IRS, Coelho BC, Lima JC, Ribeiro FG, Sampaio FPC, Pinheiro RP, et al. Description of demand in a family health unit. Rev Bras Med Fam Comunidade. 2011;6:175-81.

\section{Publisher's Note}

Springer Nature remains neutral with regard to jurisdictional claims in published maps and institutional affiliations. 